Hydrol. Earth Syst. Sci., 17, 3827-3839, 2013

www.hydrol-earth-syst-sci.net/17/3827/2013/

doi:10.5194/hess-17-3827-2013

(c) Author(s) 2013. CC Attribution 3.0 License.

\title{
Subsurface release and transport of dissolved carbon in a discontinuous permafrost region
}

\author{
E. J. Jantze ${ }^{1,2}$, S. W. Lyon $^{1,2}$, and G. Destouni ${ }^{1,2}$ \\ ${ }^{1}$ Department of Physical Geography and Quaternary Geology, Stockholm University, 10691 Stockholm, Sweden \\ ${ }^{2}$ Bert Bolin Centre for Climate Research, Stockholm University, 10691 Stockholm, Sweden
}

Correspondence to: E. J. Jantze (elin.jantze@ natgeo.su.se)

Received: 14 December 2012 - Published in Hydrol. Earth Syst. Sci. Discuss.: 9 January 2013

Revised: 10 July 2013 - Accepted: 8 August 2013 - Published: 8 October 2013

\begin{abstract}
Subsurface hydrological flow pathways and advection rates through the landscape affect the quantity and timing of hydrological transport of dissolved carbon. This study investigates hydrological carbon transport through the subsurface to streams and how it is affected by the distribution of subsurface hydrological pathways and travel times through the landscape. We develop a consistent mechanistic, pathway- and travel time-based modeling approach for release and transport of dissolved organic carbon (DOC) and dissolved inorganic carbon (DIC). The model implications are tested against observations in the subarctic Abiskojokken catchment in northernmost Sweden $\left(68^{\circ} 21^{\prime} \mathrm{N}, 18^{\circ} 49^{\prime} \mathrm{E}\right)$ as a field case example of a discontinuous permafrost region. The results show: (a) For DOC, both concentration and load are essentially flow-independent because their dynamics are instead dominated by the annual renewal and depletion. Specifically, the flow independence is the result of the small characteristic DOC respiration-dissolution time scale, in the range of $1 \mathrm{yr}$, relative to the average travel time of water through the subsurface to the stream. (b) For DIC, the load is highly flow-dependent due to the large characteristic weatheringdissolution time, much larger than $1 \mathrm{yr}$, relative to the average subsurface water travel time to the stream. This rate relation keeps the DIC concentration essentially flow-independent, and thereby less fluctuating in time than the DIC load.
\end{abstract}

\section{Introduction}

The hydrological transport of carbon has recently begun to be included in global carbon (C) budgets (Cole et al., 2007). Transport of dissolved $\mathrm{C}$ integrates terrestrial and aquatic ecosystems, and recent ecosystem assessments acknowledge the role that the lateral movement of water through aquatic systems plays for dissolved organic carbon (DOC) and dissolved inorganic carbon (DIC) cycling (Tranvik et al., 2009). Understanding the coupling between dissolved $\mathrm{C}$ and processes related to the weathering products of carbonates and silicates is important because of the long-term regulating effect of this weathering on $\mathrm{CO}_{2}$ concentrations in ocean and atmosphere (Berner, 1992). Changes in land use and climate further lead to changes in hydrological flow paths, which in turn affect dissolved nutrient fluxes (Turner and Rabalais, 2003) and C fluxes (Lyon et al., 2010).

Terrestrial high-latitude environments, which undergo particularly large climate-driven changes, have traditionally been viewed as long-term sinks of carbon. Local C sinks are then coupled to recovery of eroded soils in agricultural land during the 19th and the 20th century (Harden et al., 1999). Due to ongoing climatic warming, however, these systems can evolve such that they no longer serve as clear net carbon sinks and can potentially become large net carbon sources (Kling et al., 1991; ACIA, 2005; Fung et al., 2005; Schuur et al., 2008). In this important context, our knowledge is limited on how sources release carbon and how DOC and DIC are further transported from the ground and into streams and other aquatic ecosystems in such high-latitude terrestrial systems. 
The subsurface pathways of water flow in many arctic environments are determined by permafrost characteristics and ground ice distributions in the landscape (Carey and Woo, 2001; Framton et al., 2011; Sjöberg et al., 2013; Bosson et al., 2012). As such, the terrestrial freshwater cycle in the Arctic is intimately coupled with the existence of permafrost. The location and distribution of the subsurface hydrological pathways in turn influence the dissolved carbon release, transport and cycling through the landscape (MacLean et al., 1999; Petrone et al., 2006; McNamara et al., 2008). Also, seasonally frozen ground conditions in winter may imply prevalence of relatively deep flow pathways affecting mineral weathering (MacLean et al., 1999) and its DIC products (Lyon et al., 2010). During the spring freshet and summer seasons, there may instead be a prevalence of near-surface flow pathways through organic-rich soil horizons (Carey, 2003; Carey and Quinton, 2004) leading to increased concentrations of DOC in rivers and aquatic systems.

A more complete mechanistic understanding and quantification framework is needed to characterize current conditions and estimate potential future changes to the hydrological transport of dissolved carbon in the world. In this study, we develop such a framework and exemplify its possible application to a subarctic landscape in northern Sweden. We then use a Lagrangian approach, based on the hydrological pathways and travel times of water and solute through the landscape and its underlying geological formations, because this offers several advantages for understanding and quantification. Similar approaches have been applied to a wide range of solute (tracer, pollutant) release and transport problems in various landscape/subsurface parts, separately and linked in whole catchments (see, e.g., Destouni et al., 2010; Cvetkovic et al., 2012, and references therein). Owing to its flexibility, such a Lagrangian framework can provide a hydrologically consistent manner by which to explore the release, transport and export of dissolved carbon from terrestrial arctic landscapes. Lyon et al. (2010), for instance, used this approach to interpret measured DOC and DIC transport to the stream in the Swedish subarctic Abiskojokken catchment and quantify average rates $(r$, in terms of mass release per unit time and bulk soil volume $\left[\mathrm{M} \mathrm{T}^{-1} \mathrm{~L}^{-3}\right]$ ) of organic and inorganic carbon release/dissolution into soil water.

The aim of the present study is to further develop the Lagrangian approach to DOC and DIC release and transport from subsurface to surface water systems, and to use this approach to further resolve, distinguish and quantify the mechanisms and controls that underlie the release rate $r$ for DOC and DIC in the specific example of the Abiskojokken catchment, located in a discontinuous permafrost region. This study is structured as follows. In the methods section we first describe the Abiskojokken catchment and the observed export patterns and hydrogeochemical signals of DOC and DIC in that catchment. We further develop and describe the mechanistic Lagrangian framework by which the available observation data are interpreted to infer the DOC and DIC source inputs and transport through the subsurface hydrological pathways in the landscape of the Abiskojokken catchment, which includes seasonal frost and permafrost. For the model development and interpretation application, we link different previous model development components (e.g., the characteristic travel time and release time) (Eriksson and Destouni, 1997; Lyon et al., 2010) into the present pathwayand travel time-based modeling framework for diffuse source release and transport of dissolved carbon. In the results section, we show and explain the implications of the developed mechanistic modeling framework for the dynamics of DOC and DIC export, and then compare these implications with the available observations of the dynamics of streamflow and relevant water chemistry in Abiskojokken. We further discuss the results in a separate discussion section and outline our overall conclusions in the conclusions section.

\section{Methods}

\subsection{Site description: the Abiskojokken catchment}

The Abiskojokken catchment $\left(68^{\circ} 21^{\prime} 36^{\prime \prime} \mathrm{N}, 18^{\circ} 46^{\prime} 48^{\prime \prime} \mathrm{E}\right)$ is situated in the Abisko region, a glacially eroded subarctic environment $200 \mathrm{~km}$ north of the Arctic Circle (Fig. 1). The catchment has an area of $566 \mathrm{~km}^{2}$ and its elevation ranges from $350 \mathrm{~m}$ to $1600 \mathrm{~m}$ a.s.l. (above sea level). Abisko had a mean annual precipitation of $304 \mathrm{~mm} \mathrm{yr}^{-1}$ in the reference time period 1961-1990 (Swedish Meteorological and Hydrological Institute - SMHI) but there is a strong gradient in precipitation with elevation in the catchment. Mean annual air temperature for the same time period was $-0.8^{\circ} \mathrm{C}$ (SMHI, station no. 18880, Abisko), but it has since 2000 significantly exceeded $0{ }^{\circ} \mathrm{C}$, which is a threshold for many ecological and cryospheric processes (Callaghan et al., 2010). Permafrost in the Abisko region is discontinuous (Brown et al., 1998; Johansson et al., 2006) and decreases in coverage along a gradient from west to east. Regionally, Sjöberg et al. (2013) have shown presence and change of permafrost in northern Swedish catchments over the past decades. The permafrost distribution is patchy and shows a strong relationship with elevation; about $73 \%$ of the catchment area is situated above $800 \mathrm{~m}$, which is an elevation threshold for probable presence of permafrost in the Abisko region (Ridefelt et al., 2008). The presence and quality of permafrost varies on a small spatial scale under the influence of topography, snow cover amount and duration, as well as local hydrological conditions (Kneisel, 2010). An average permafrost thawing rate for the Abiskojokken catchment has been estimated through recession flow analysis to have been $0.9 \mathrm{~cm} \mathrm{yr}^{-1}$ during the past $90 \mathrm{yr}$ (Lyon et al., 2009).

The bedrock in the catchment is dominated by mica schists and calcite marble (Kulling and Geijer, 1960). While there is no detailed soil characterization available for the Abiskojokken catchment, the median depth of the till-dominated 

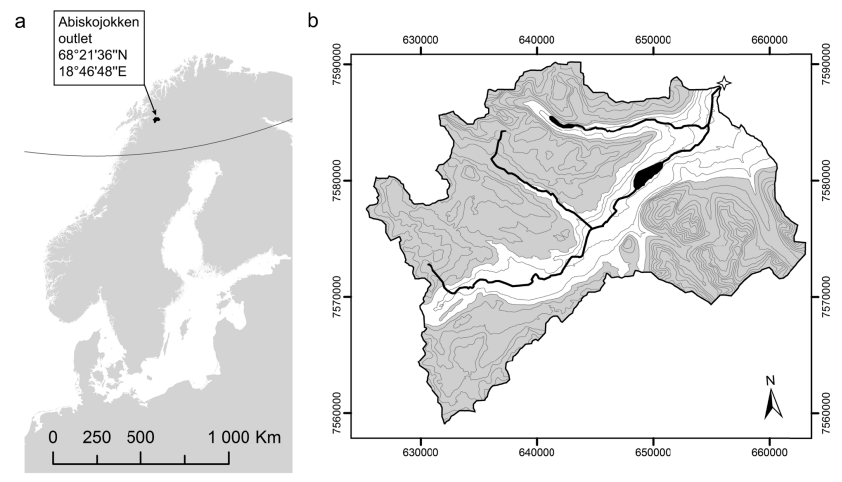

Fig. 1. (a) Map of Scandinavia with Abiskojokken catchment in northern Sweden (marked in black) and the polar circle (marked by line). (b) Site map of Abiskojokken catchment with $73 \%$ of the catchment situated above $800 \mathrm{~m}$ a.s.l. (shaded gray); the outlet is marked by a star $\left(68^{\circ} 21^{\prime} 36^{\prime \prime} \mathrm{N}, 18^{\circ} 46^{\prime} 48^{\prime \prime} \mathrm{E}\right)$. The coordinate system is given in SWEREF 99.

unconsolidated sediments has been estimated to range between $5 \mathrm{~m}$ for deciduous forest to about $7 \mathrm{~m}$ for herbaceous vegetation in this region (Smedberg et al., 2009), and regional studies of nearby Kärkevagge show typically coarseloamy soils with $5 \%$ clay with a slightly acidic soil $\mathrm{pH}$ (Darmody et al., 2000). The subalpine birch forest (Betula pubescens tortuosa) in the Abisko valley generally reaches $650 \mathrm{~m}$ a.s.l., and up to $700 \mathrm{~m}$ a.s.l. on south-facing slopes. The ground is generally dry and the undergrowth is speciespoor. Above the birch forest the vegetation shifts to willow (Salix sp.) and dwarf birch (Betula nana) dominated heaths. Above the heaths the vegetation transitions into dry shrubland and meadows with low herbs. Middle alpine grass heaths dominate at elevations higher than $1000 \mathrm{~m}$ a.s.l. (Rafstedt et al., 1985).

\subsection{Observations and analysis}

Publically available long-term hydrological and stream chemistry data make it possible to utilize the Abiskojokken for this study. Monthly stream chemistry data, including alkalinity $\left(\mathrm{mekv} \mathrm{L}^{-1}\right)$ and total organic carbon (TOC, $\mathrm{mg} \mathrm{L}^{-1}$ ), are available for Abiskojokken for the period 1982 to 2011 through a systematic monitoring program carried out by the Swedish University of Agricultural Sciences (SLU), Department of Environmental Assessment. We have further used the short-term stream chemistry data for alkalinity $\left(\mathrm{mmol} \mathrm{L}^{-1}\right)$, and DOC $\left(\mathrm{mg} \mathrm{L}^{-1}\right)$ and DIC $\left(\mathrm{mg} \mathrm{L}^{-1}\right)$ concentrations reported by Lyon et al. (2010) for the year 2008 to also estimate long-term monthly concentrations of DOC and DIC for Abiskojokken. There is namely a strong relation between the long-term data of monthly TOC in Abiskojokken and the short-term DOC data of Lyon et al. (2010) $\left(r^{2}=0.98\right.$; [TOC] $=1.195 \cdot[\mathrm{DOC}]-0.28$, see Fig. A1, Appendix A), such that DOC can be considered essentially equivalent to TOC for this system. For long-term DIC, there is further a strong linear relationship between the long-term data for alkalinity and the short-term DIC data of Lyon et al. $(2010)\left(r^{2}=0.99 ;\right.$ [alk] $=0.77 \cdot[\mathrm{DIC}]-0.0071$, see Fig. A2, Appendix A). This DIC relationship was used to translate the available long-term monthly alkalinity values into long-term monthly DIC concentrations. Daily streamflow for Abiskojokken is further available from the Swedish Meteorological and Hydrological Institute (SMHI; Gage ID 957) from 1986 to 2010; we then calculated monthly and annual total discharges $\left(\mathrm{m}^{3} \mathrm{yr}^{-1}\right)$ for this period. Annual mass flux of DOC and DIC was calculated from 1986 to 2010 as the annual sum of the monthly total mass flux (the product of concentration and monthly total water discharge, Fig. 2). Annual flow-weighted mean concentrations $\left(\mathrm{g} \mathrm{m}^{-3}\right)$ for DOC and DIC were finally calculated by dividing the respective annual mass flux by the total annual water discharge. This simple approach to estimate annual mass loads and flowweighted concentrations of DOC and DIC was used instead of other approaches (e.g., LOADEST as in Tank et al., 2012) since the current study (and essentially the modeling framework developed) is primarily focused on variability of annual export rather than on short-term load fluctuations. As such, the potential influence of the interpolation method on annual load estimates is assumed to be small with regard to the scope of the present study. Based on statistical analysis, the annual flow-weighted mean concentration of DOC determined for the year 1989 was further formally removed as an outlier, as it was more than twice the interquartile range above the median of the annual data, and not considered in further analysis. Closer inspection of the monthly observations from 1989 showed that the peak observed DOC concentration did not correspond to the observed annual streamflow peak and observed minimum DIC concentration, which is atypical for this system according to Giesler et al. (2013). This provides further support for removing the 1989 DOC concentration as an outlier.

The resulting time series of annual flow-weighted DOC and DIC concentrations, annual DOC and DIC mass fluxes, and annual total discharge for the Abiskojokken catchment were further analyzed for trends (at a significance level of $\alpha=0.1$ ), using the generalized least squares approach (Box et al., 2008) after removal of autocorrelation with the Durbin-Watson test in agreement with the methodology put forward by Durbin and Watson $(1950,1951,1971)$. In addition, the correlations of DOC and DIC export concentrations and of corresponding mass fluxes with total annual discharge were assessed.

\subsection{A mechanistic framework for modeling of solute release and transport}

Starting from Lyon et al. (2010), the concentration, $c\left[\mathrm{ML}^{-3}\right.$ water], and mass flux, $s\left[\mathrm{ML}^{-2} \mathrm{~T}^{-1}\right]$, (Table 1) of DOC or DIC exported through a stream cross-section from an 
Table 1. Model parameters and estimated parameter value estimates (standard deviation within parentheses) for the Abiskojokken catchment.

\begin{tabular}{|c|c|c|c|c|}
\hline Parameter & Measure & Dimensions & Values & Data source \\
\hline \multirow[t]{2}{*}{$c$} & $\begin{array}{l}\text { Annual flow-weighted } \\
\text { mean concentration }\end{array}$ & {$\left[\mathrm{ML}^{-3}\right]$} & $\begin{array}{l}c_{\mathrm{DOC}}=1.60(0.339) \\
\mathrm{g} \mathrm{m}^{-3}\end{array}$ & SLU \\
\hline & & & $\underset{\mathrm{g} \mathrm{m}^{-3}}{c_{\text {DIC }}=2.66}(0.291)$ & SLU, Lyon et al. (2010) \\
\hline$s$ & Mass flux $s=c q_{\mathrm{s}}$ & {$\left[\mathrm{M} \mathrm{L}^{-2} \mathrm{~T}^{-1}\right]$} & & \\
\hline \multirow[t]{2}{*}{$S$} & Mass flow rate $S=c Q$ & {$\left[\mathrm{M} \mathrm{T}^{-1}\right]$} & $\begin{array}{l}S_{\mathrm{DOC}}=697878 \\
(139750) \text { tons } \mathrm{yr}^{-1}\end{array}$ & SLU \\
\hline & & & $\begin{array}{l}S_{\text {DIC }}=1187389 \\
(237484) \text { tons } \mathrm{yr}^{-1}\end{array}$ & SLU, Lyon et al. (2010) \\
\hline$q_{\mathrm{s}}$ & Specific discharge & {$\left[\mathrm{L} \mathrm{T}^{-1}\right]$} & & \\
\hline$Q$ & Total annual discharge & {$\left[\mathrm{L}^{3} \mathrm{~T}^{-1}\right]$} & $\begin{array}{l}446866103 \\
(78788597) \mathrm{m}^{3} \mathrm{yr}^{-1}\end{array}$ & SMHI \\
\hline$r$ & DOC/DIC dissolution rate & {$\left[\mathrm{M} \mathrm{T}^{-1} \mathrm{~L}^{-3}\right]$} & & \\
\hline$k$ & $\begin{array}{l}\text { Release rate constant, with } \\
1 / k \text { quantifying a characteristic } \\
\text { time for the entire } c_{0}^{*} \text { to dissolve }\end{array}$ & {$\left[\mathrm{T}^{-1}\right]$} & & \\
\hline$\tau$ & $\begin{array}{l}\text { Advective (water) travel time } \\
\text { through the stream tube }\end{array}$ & {$[\mathrm{T}]$} & & \\
\hline$\theta$ & $\begin{array}{l}\text { Average volumetric water } \\
\text { content }\end{array}$ & {$[-] \frac{\left[\mathrm{L}^{3} \text { water }\right]}{\left[\mathrm{L}^{3} \text { bulk }\right]}$} & & \\
\hline
\end{tabular}

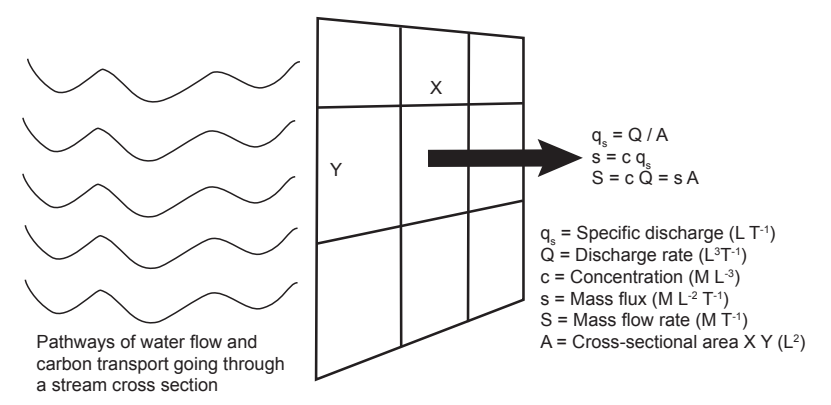

Fig. 2. Schematic representation of specific discharge $\left(q_{\mathrm{s}}\right)$ and mass flux $(s)$ in terms of concentration $(c)$ and discharge flow rate $(Q)$ with associated cross-sectional area $(A)$.

individual pathway, or stream tube, of water flow and solute transport (Fig. 2), originating from the land surface and going through the soil-groundwater system to the stream (Fig. 3), can be expressed as

$c=r \frac{\tau}{\theta} \quad$ and $s=r \frac{q_{\mathrm{s}} \tau}{\theta}$,

where $r$ is the average release (dissolution) rate $\left[\mathrm{M} \mathrm{T}^{-1} \mathrm{~L}^{-3}\right]$ of DOC or DIC in the stream tube, $\tau$ is the advective (water) travel time [T] through the stream tube (essentially the time for 1 pore volume of water to flow through the stream tube), $\theta$ is the average volumetric water content (-) $\left[\mathrm{L}^{3}\right.$ water $\mathrm{L}^{-3}$ bulk] (equals the porosity under fully saturated groundwater conditions), and $q_{\mathrm{s}}$ is the local specific groundwater discharge (Darcy flux) $\left[\mathrm{L} \mathrm{T}^{-1}\right]$ flowing into the stream through the interface with the sediment-groundwater system. The term stream tube is used to describe mass transport through an infinitesimal three-dimensional space centered around and along each of the hydrological pathways (streamlines, trajectories) of water flow and solute transport illustrated in Figs. 2-3. The terms stream tube, streamline, trajectory, and hydrological pathway are defined and used similarly as in earlier work considering transport in steady groundwater flow by Cvetkovic and Dagan (1994), through the linked unsaturated soil water-saturated groundwater flow system by Destouni and Graham (1995), through the linked groundwater-stream system by Lindgren et al. (2004), and through multiple hydrologically and/or hydrochemically different parts of a whole catchment by Cvetkovic et al. (2012), to which we refer the reader for further mechanistic and physical explanation details.

Neglecting local dispersion and molecular diffusion, and considering the simplest case of constant release (dissolution) rate (zeroth-order kinetics) from the solid into the mobile water phase, $r$ can be further resolved and expressed (Eriksson and Destouni, 1997) as

$r=\frac{\mathrm{d} c^{*}}{\mathrm{~d} t}=-k c_{0}^{*}$

where $t$ is the running time [T], $c^{*}$ is the average bulk concentration $\left[\mathrm{ML}^{-3}\right.$ bulk] of organic carbon in the soil for DOC and inorganic carbon in the solid phase of the (soil, unconsolidated sediment, bedrock) stream tube for DIC, $c_{0}^{*}$ is the initial $c^{*}$ at time $t=0$, and $k$ is a release rate constant 


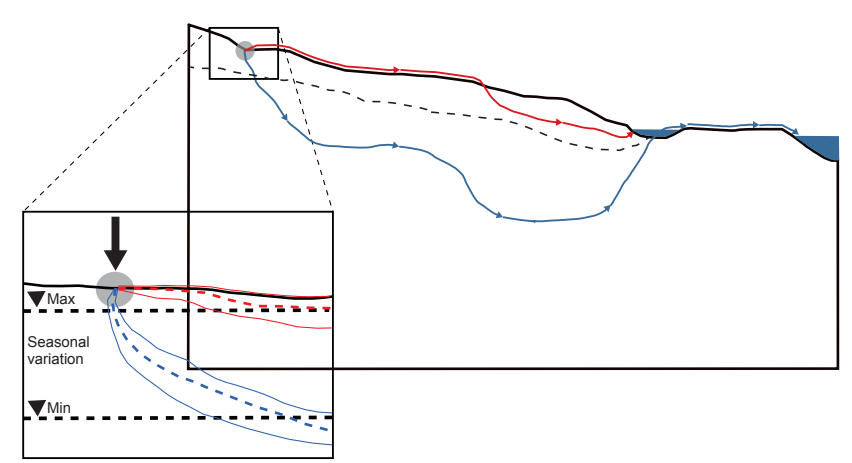

Fig. 3. Examples of different pathways of water flow and solute transport emerging from an arbitrary recharge location in a catchment. A statistical ensemble of pathways is obtained when considering all recharge locations over the entire area of a catchment. The thick dashed lines indicate main average pathways and the thin dashed lines indicate examples of individual pathway variations (in space) and fluctuations (in time) around each mean. Depending on boundary conditions and catchment-internal structure (including prevailing average groundwater level and its fluctuations), water flow and solute flux will be partitioned differently between the two main (thick, dashed) mean pathways. Modified after Cvetkovic et al. (2012).

$\left[\mathrm{T}^{-1}\right]$ (with $1 / k$ quantifying a characteristic time for the entire initial bulk concentration $c_{0}^{*}$ to dissolve). Inserting Eq. (2) into Eq. (1) (through $r$ ) and solving for initial conditions $c^{*}(0)=c_{0}^{*}$ and $c(0)=0$ throughout the entire stream tube and boundary condition $c(t, 0)=0$ (zero concentration in incoming water to the stream tube) yields a relevant set of solutions for solute concentration $c$ and mass flux $s$ in the water flowing from the soil-groundwater stream tube into the stream at time $t$ based on Eriksson and Destouni (1997).

For travel time $\tau \leq 1 / k$ (with $c_{0}^{*}$ dissolving entirely at time $t=1 / k$, the first pore volume of water having flowed through the stream tube at time $t=\tau$ ) and different running time $t$, the resulting solution expressions for concentration $c$ and mass flux $s$ are:

$$
\begin{aligned}
& - \text { for } t \leq \tau \\
& \qquad \frac{\theta c}{c_{0}^{*}}=k t ; \quad \frac{\theta s}{q_{\mathrm{s}} c_{0}^{*}}=k t, \\
& - \text { for } \tau<t \leq 1 / k \\
& \qquad \frac{\theta c}{c_{0}^{*}}=k \tau ; \quad \frac{\theta s}{q_{\mathrm{s}} c_{0}^{*}}=k \tau \text { and } \\
& - \text { for } 1 / k<t \leq 1 / k+\tau \\
& \qquad \frac{\theta c}{c_{0}^{*}}=k(\tau-1)+1 ; \quad \frac{\theta s}{q_{\mathrm{s}} c_{0}^{*}}=k(\tau-1)+1 .
\end{aligned}
$$

For travel time $\tau>1 / k$ and different running time $t$, the resulting solution expressions for concentration $c$ and mass flux $s$ are:

$$
\begin{aligned}
& - \text { for } t \leq 1 / k \\
& \qquad \frac{\theta c}{c_{0}^{*}}=k t ; \quad \frac{\theta s}{q_{\mathrm{s}} c_{0}^{*}}=k t, \\
& - \text { for } 1 / k<t \leq \tau \\
& \qquad \frac{\theta c}{c_{0}^{*}}=1 ; \quad \frac{\theta s}{q_{\mathrm{s}} c_{0}^{*}}=1 \text { and } \\
& - \text { for } \tau<t \leq \tau+1 / k \\
& \frac{\theta c}{c_{0}^{*}}=k(\tau-1)+1 ; \quad \frac{\theta s}{q_{\mathrm{s}} c_{0}^{*}}=k(\tau-1)+1 .
\end{aligned}
$$

The solutions expressed by Eqs. (3)-(4) apply for solute release and transport through a single stream tube (individual pathway in Figs. 2-3), characterized by a single value of $\tau$. Averaging over the whole ensemble of different stream tubes (all possible pathways in Figs. 2-3), with associated different $\tau$, yields flux-averaged concentration $\overline{c_{\mathrm{f}}}$ and average mass flux into the stream network (Lyon et al., 2010) as

$$
\begin{aligned}
\overline{c_{\mathrm{f}}} & =\frac{1}{\bar{q}_{\mathrm{s}}} \int_{0}^{\infty}\left(c q_{\mathrm{s}}\right) g(\tau) \mathrm{d} \tau \\
& =\frac{1}{\bar{q}_{\mathrm{s}}} \int_{0}^{\infty} s g(\tau) \mathrm{d} \tau ; \quad \text { and } \bar{s}=\overline{c_{\mathrm{f}}} \cdot \overline{q_{\mathrm{s}}},
\end{aligned}
$$

where $\overline{q_{\mathrm{s}}}$ is the average water flux and $g(\tau)$ is the probability density function (pdf) that quantifies the spatial distribution of advective solute travel times $\tau$ among all the different possible pathways through the catchment to the stream system (Fig. 3). The catchment-average mass flux $\bar{s}=\overline{c_{\mathrm{f}}} \cdot \overline{q_{\mathrm{s}}}$ in Eq. (5) follows directly from the definition of flux-averaged concentration on the catchment scale $\overline{c_{\mathrm{f}}}$, in which the integral $\int_{0}^{\infty} s g(\tau) \mathrm{d} \tau$ is by definition the average mass flux $\bar{s}$. For further physical explanation and quantification of the difference between the flux-averaged concentration $\overline{c_{\mathrm{f}}}$ and a simple average (also called average resident) concentration expression $\bar{c}=\int_{0}^{\infty} c g(\tau) \mathrm{d} \tau$, and on the direct relation of (only) $\overline{c_{\mathrm{f}}}$ with the large-scale average mass flux $\bar{s}=\overline{c_{\mathrm{f}}} \cdot \overline{q_{\mathrm{s}}}$, we refer the reader to Destouni and Cvetkovic (1991; specifically their Sect. 5: Comparison between the flux-averaged and the resident concentration models).

Equations (3)-(5) provide a generic framework for solute release and transport through a catchment, which can be used to quantify different cases of subsurface DOC and DIC release and subsequent transport into streams. Different types and forms of the pdf $g(\tau)$ are possible and relevant for different catchment conditions (Lindgren et al., 2004; Cvetkovic, 2011; Persson et al., 2011). In the following section, we test and illustrate results of the catchment-average solution Eq. (5) for the simple example of uniform $g(\tau)$, with $0 \leq \tau \leq 2 E[\tau]$ and $E[\tau]$ being average $\tau$. This $g(\tau)$ choice 
is made for its simplicity and because it allows for purely analytical solutions. Other, more realistic functions for $g(\tau)$ have for instance been studied by Persson et al. (2011) and Cvetkovic (2011), and their often greater $\tau$ variability than that studied here for uniform $g(\tau)$ is likely to further enhance the main implications of spatial $\tau$ variability that are shown and discussed in the following.

\section{Results}

\subsection{DOC and DIC release and transport dynamics}

\subsubsection{The DOC case}

The aim of the calculation examples in this section is to demonstrate what the flow-independent dynamics of normalized (with $q_{\mathrm{s}}$ and/or $\overline{q_{\mathrm{s}}}$ ) concentration $c$ and mass flux $s$ from Eqs. (3)-(5) may look like under various conditions of relevance for DOC and DIC release and transport. This exemplification is done for a single pathway (stream tube) with a single travel time $\tau=1 \mathrm{yr}$, as well as for an ensemble of pathways (stream tubes) with variable (uniformly distributed) $\tau$ with an average value of $1 \mathrm{yr}$. For DOC, $c_{0}^{*}$ represents the bulk concentration of organic material in the organic horizon, which is annually renewed, dissolved and transported as DOC to streams each year. This annual periodicity implies that the characteristic DOC release time $1 / k$ should be on the order of $1 \mathrm{yr}$ or smaller. The reported order of magnitude of mean advective travel time, $\tau$, through the soilgroundwater system of the Abiskojokken catchment is also about 1 yr (Lyon et al., 2010), as has been reported for average $\tau$ also in other, regionally relevant, Swedish catchments (Darracq et al., 2010; Persson et al., 2011). The reported value of $1 \mathrm{yr}$ by Lyon et al. (2010) was obtained using a distributed travel time model based on Darcy's Law, which was regionally supported by use of isotope tracers in a nearby catchment by Burgman et al. (1987). Similar average $\tau$ and $1 / k$ magnitudes (of around $1 \mathrm{yr}$ for both) imply that any and all of the different Eqs. (3)-(4) may apply to the case of DOC release and transport through the different possible individual stream tubes of a catchment that are included in the integration over the entire travel time pdf $g(\tau)$ in Eq. (5).

Figure 4 shows resulting calculated dynamics of possible DOC transport, in terms of normalized concentration $c \theta / c_{0}^{*}$ and mass flux $s \theta /\left(q_{\mathrm{s}} c_{0}^{*}\right)$ in a single stream tube (single $\tau$; Fig. $4 \mathrm{a})$, and $\bar{c}_{\mathrm{f}} \theta / c_{0}^{*}$ and $\bar{s} \theta / \overline{q_{\mathrm{s}}} c_{0}^{*}$ over a whole catchment (variable $\tau$; Fig. $4 \mathrm{~b}$ ), for different (single stream tube or catchment-average) $\tau$ and release rate $k$ (or characteristic release time scale $1 / k$ ). For any given travel time $\tau$ (for single stream tube or catchment-average; here $1 \mathrm{yr}$ ), a lower average release rate $k$ implies longer time $1 / k$ to complete dissolution of the annually renewed soil source of DOC $\left(c_{0}^{*}\right)$ as well as longer time to reaching a stable average concentration
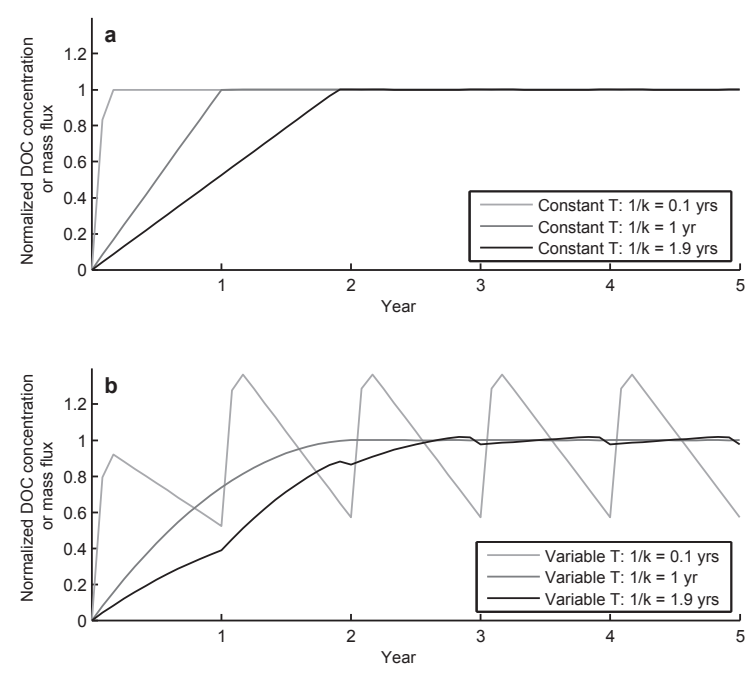

Fig. 4. DOC transport dynamics. (a) Results for a single stream tube with a single travel time, $\tau=1 \mathrm{yr}$. (b) Results for an ensemble of stream tubes with variable (uniformly distributed) $\tau$, and average $\tau=1 \mathrm{yr}$. The results show how the release rate $k$ (or characteristic release time $1 / k$ ) affects DOC concentration and mass flux from the soil-groundwater into the stream system.

and mass flux level (even though with possible fluctuations around the latter for different $\tau$ conditions; Fig. 4b).

For release and transport along a single pathway (stream tube) with a single $\tau$ value (Fig. 4a), the flow-normalized $c$ and $s$ do not fluctuate around their average levels. The corresponding catchment-average $\bar{c}_{\mathrm{f}}$ and $\bar{s}$, however, can clearly fluctuate in time even for temporally constant $c_{0}^{*}, \theta$ and $q_{\mathrm{s}}$, which have here been used for normalization (Fig. $4 \mathrm{~b}$ ). The local single pathway (or stream tube) and catchmentaverage (for the whole ensemble of pathways) results differ temporally due to the spatial $\tau$ variability accounted for in the latter. This variability implies different temporal evolution with increasing time $t$ for the different solution components of Eqs. (3)-(4) that apply to different pathways (stream tubes) in the catchment. The temporal fluctuations in the catchment-average results increase with decreasing average dissolution time $1 / k<1 \mathrm{yr}$ (see example $1 / k=0.1 \mathrm{yr}$ compared with $1 / k=1 \mathrm{yr}$ in Fig. $4 \mathrm{~b}$ ). For average dissolution time $1 / k \geq 1 \mathrm{yr}$, the fluctuations are overall smaller than for $1 / k<1$, and they disappear when $1 / k$ values reach integer multiples of the source renewal rate of $1 \mathrm{yr}$ (see $1 / k=1.9 \mathrm{yr}$ and $1 / k=1 \mathrm{yr}$ in Fig. $4 \mathrm{~b}$ ). The temporal variability of fluxaverage concentration, obtained for a whole ensemble of spatially variable pathways through Eq. (5) (Fig. 4b), may in the DOC case also dominate the dynamics of catchment-average mass flux, which may then be essentially independent of the temporal variability in water discharge. We will further investigate this hypothesis using observation data from the 
Abiskojokken catchment, which are independent of the calculation results for Eqs. (3)-(5) that have been exemplified and discussed in this section.

\subsubsection{The DIC case}

For the case of DIC, $c_{0}^{*}$ represents the average bulk mineral concentration in the whole unconsolidated sediment and bedrock system where weathering can occur and dissolve inorganic carbon under the surface of the catchment. This is a relatively slow process (compared to the respiration and dissolution rates for organic carbon), so that complete depletion of $c_{0}^{*}$ (which is not renewed in the DIC case) can be expected to take a long time. This is quantified by a much greater characteristic dissolution time $1 / k$ than the average $\tau$ of $1 \mathrm{yr}$. Under such conditions, Eq. (3b) for $\tau<t \leq 1 / k$ is more or less generally applicable for most (if not all) prevailing subsurface flow and transport pathways (stream tubes) through a catchment. This means that the DIC concentration is in this case predominantly determined by the average $k \tau$ value (i.e., the relation $\tau /(1 / k)$ between average advective travel time and time to total dissolution). In other words, the flux-average concentration of DIC should not exhibit the dynamic fluctuation effect evident for DOC (Fig. 4b), since that effect is due to different solution components of Eqs. (3)-(4) applying to stream tubes with different $\tau$ in the catchment-average solution Eq. (5). This expectation is confirmed by calculation results for a large dissolution time scale $1 / k$ ( $\gg$ average $\tau$; Fig. 5), as should be relevant for DIC release and transport. It should be noted that the DIC concentration becomes temporally stable already for $1 / k=3 \mathrm{yr}$, with greater dissolution times $1 / k$ yielding lower concentration levels (see examples of $1 / k=100 \mathrm{yr}$ and $1 / k=1000 \mathrm{yr}$ in Fig. 5).

As a consequence, the dynamics of catchment-average mass flux $\bar{s}$ should for DIC be dominated by the temporal variability of local $\left(q_{\mathrm{s}}\right)$ and catchment-average $\left(\overline{q_{\mathrm{s}}}\right)$ discharge. Minor contributors to the behavior of $\bar{s}$ are the hydrological parameters $\theta$ and $\tau$, and a possible decrease in the bulk mineral source $c^{*}$ as the weathering and dissolution progress with time. The latter possibility has for simplicity been neglected in the underlying dissolution Eq. (2), as this effect has been investigated and shown previously by Eriksson and Destouni (1997) and will not affect the main results and implications of the present study. The temporal variability effects of $\theta$ and $\tau$ are expected to be much smaller than the effect of temporal variability in discharge $\left(q_{\mathrm{s}}\right.$ and $\left.\overline{q_{\mathrm{s}}}\right)$. This implies that we expect the DIC mass flux measured in the field to be highly correlated with the measured stream discharge, while the DIC concentration should be much less variable in time and essentially uncorrelated with discharge. This DIC expectation will in the following section be tested against available data from the Abiskojokken catchment, along with the complementary hypothesis formulated above for DOC.

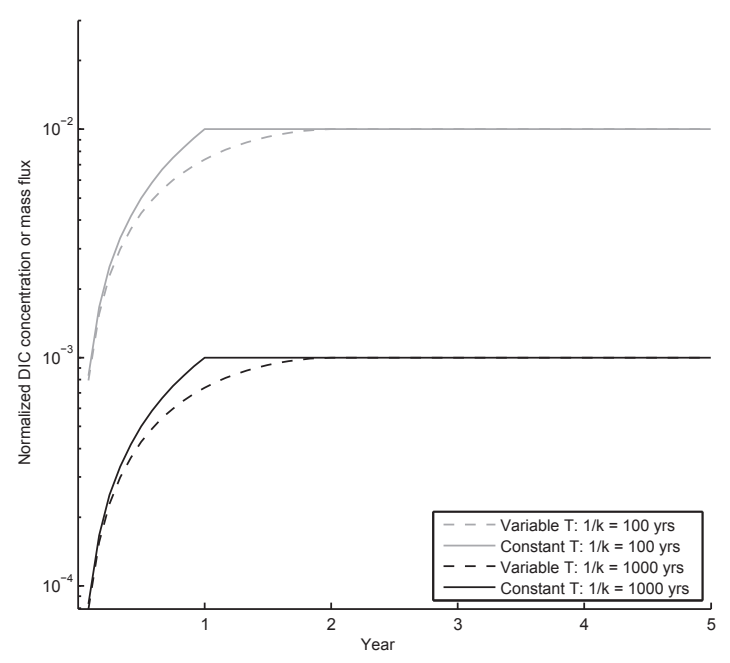

Fig. 5. DIC transport dynamics. Results are shown on log scale for single travel time ( $\tau=1 \mathrm{yr}$; solid curves) and variable, uniformly distributed $\tau$ (with average value of $1 \mathrm{yr}$; dashed curves) for different values of release rate $k$ (or characteristic release time $1 / k$ ).

\subsection{Interpreting observed data from the Abiskojokken catchment}

\subsubsection{Time series analysis of observed data}

The total annual water discharge exhibits a significant decreasing trend $(p=0.078 ; p<\alpha)$ over the period of observation in the Abiskojokken catchment (between 1986 and 2010; Fig. 6). For the same time period there is a significant positive trend $(p=0.060 ; p<\alpha)$ in the annual flowweighted average DIC concentration (Fig. 7a), while the annual flow-weighted average DOC concentration is essentially constant. There are no significant trends in the total annual mass flux of either DIC or DOC over the period (Fig. 7b).

\subsubsection{Observed data dynamics compared with model results}

Taken together, the relationship between observed mass flux and concentration fluctuations, and the results of the mechanistic model provide a lens through which to directly interpret the above-mentioned trends (or lack thereof) in DOC/DIC concentrations and loads (Figs. 7 and 8). Starting with the significant trend exhibited by the water discharge over the observation period in Abiskojokken (Fig. 6), this reflects a temporally sustained flow decrease over the whole catchment and, most importantly, over sufficiently long time (rather than just being a short-term fluctuation) to also affect the average water travel time $\tau$ through the catchment. The discharge decrease trend is consistent with previously reported shifts in both observed (Lyon et al., 2009; Dahlke 


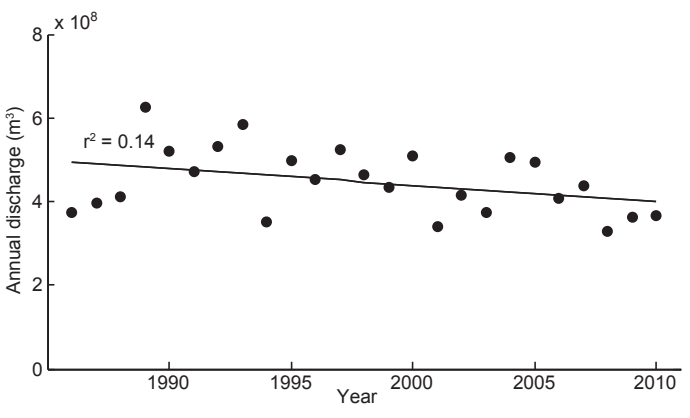

Fig. 6. Annual discharge between 1986 and 2010 at the outlet of Abiskojokken catchment. The discharge exhibits a significant $(p=$ 0.078) negative trend.

et al., 2012) and modeled (Sjöberg et al., 2013) hydrological flow, primarily due to thawing of permafrost and secondarily due to shifted climatic forcing (mainly temperature increase) (Dahlke et al., 2012). Furthermore, the DIC concentration decrease trend is consistent with increasing average $\tau$ in the most relevant mechanistic model solution, Eq. (3b), for DIC. The observed increasing DIC concentration is thus explained by the significant discharge and associated $\tau$ trends. The DIC-relevant Eq. (3b) further shows that the discharge decrease and $\tau$ increase trends counteract each other in the mass flux expression, leaving the DIC mass flux essentially unchanged, as is also independently observed in the field (Fig. 7b). For the DOC concentration, the dynamic effect induced by the spatial $\tau$ variability is sufficiently dominant to override and mask the discharge decrease and $\tau$ increase trends, so that the observed annual flow-weighted average DOC concentration does not exhibit any significant trend over the observation period.

\section{Discussion}

\subsection{Relationship between observed and modeled C dynamics}

As expected from the mechanistic model implications, the fluctuations of annual flow-weighted average DIC concentration around its mean trend is essentially independent of the discharge fluctuations (Fig. 8a), while the fluctuations in annual DIC mass flux show high positive correlation with the fluctuations in annual discharge (Fig. 8b). While some spatial variability likely exists also in weathering rates, for instance, between higher altitudes and lower valley bottoms (e.g., Allen et al., 2001; Dixon et al., 2008), high correlation between solute mass flux and water discharge (Fig. 8b) has also been found in other studies, for diffuse solute inputs from geogenic sources or for inputs from subsurface sources that have been formed over time as legacies of earlier anthropogenic solute inputs at the land surface (Godsey et al., 2009; Basu et al., 2010).
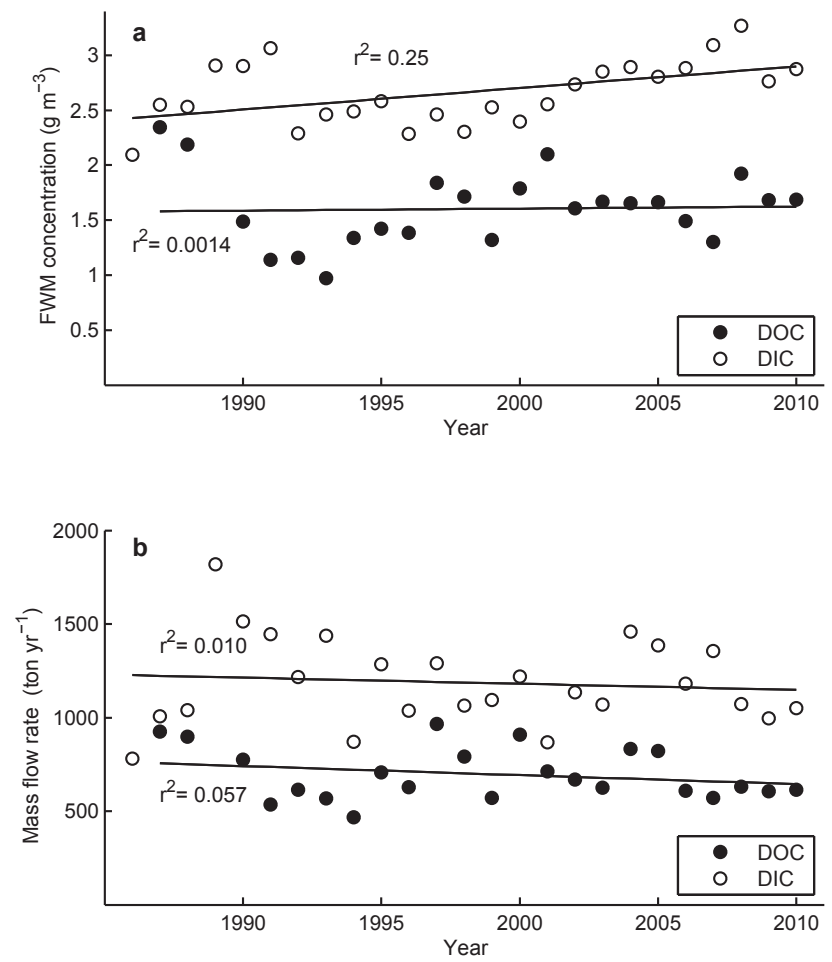

Fig. 7. Dissolved carbon time series. (a) Annual flow-weighted mean (FWM) concentration of DOC and DIC at the outlet of Abiskojokken catchment. The DIC concentration exhibits a significant $(p=0.060)$ positive trend. (b) Annual mass flow rate of DOC and DIC at the outlet of Abiskojokken catchment; the relation between mass flow rate, $S$, and mass flux, $s$, is as shown in Fig. 2.

Across six large arctic catchments, Tank et al. (2012) further found that annual DIC mass flux is positively correlated with discharge and with the presence of carbonate rock. DIC loading from the subarctic landscape at the scale of the Abiskojokken catchment, as such, appears to be associated with the diffuse and relatively slow DIC release from rather ubiquitous weathering across the entire catchment. Release time of DOC is likely to be enhanced under climatic warming, due to a prolonged growing season and/or enhanced breaking down of organic material. Release times of DIC from the ubiquitous weathering are not likely to change due to climate warming, but transformation from organic to inorganic carbon has been found to increase with contact time with mineralogenic sediments (Kawahigashi et al., 2006).

The ubiquitous weathering interpretation of DIC results is consistent with recent work relating the easily weatherable carbonaceous bedrock (specifically $\mathrm{Ca} / \mathrm{Na}$ ratio) with DIC in streams across spatial scales for this region (Giesler et al., 2013). Furthermore, the interpretation of high DIC mass flux correlation with discharge is coherent with that wet years result in relatively greater increase in DIC export than in DOC export (Olefeldt et al., 2012). As such, the large average dissolution time scale $(1 / k \gg$ average $\tau)$ relevant for weathering and its byproducts (i.e., for DIC) makes the mechanistic 
solution component Eq. (3b) predominant. The DIC concentration is then controlled at a similar stable level, as determined by average $k \tau$, throughout most or all the flow and transport pathways (stream tubes) through the catchment, as described in Sect. 2.3. Not only $k$ but also average $\tau$ is to a large degree independent of the temporal fluctuations of discharge into the stream, because the whole flow and transport process through the soil-groundwater system to the stream, which determines average $\tau$, is not much affected by (or correlated with) the most downstream discharge $\left(\overline{q_{\mathrm{s}}}\right)$ and its temporal fluctuations precisely at the stream interface.

As also expected from the mechanistic model implications, and counter to the DIC behavior, the fluctuations of both the annual flow-weighted DOC concentration (Fig. 8a) and the annual DOC mass flux (Fig. 8b) are essentially uncorrelated with the discharge fluctuations. We recall here that the basis for expecting this discharge independence is the above-discussed dynamic effect of spatially variable $\tau$ in the DOC case (which is not the case for DIC, for which $1 / k \gg$ average $\tau$ ). Additional dynamic DOC effects can be partly attributed to the variable nature of decomposition rates for organic material and the associated release rate for DOC, which are coupled to numerous factors such as temperature, vegetation type and soil moisture distribution (Clark et al., 2005; Hobbie et al., 2000; Lyon et al., 2011; Seibert et al., 2009; Sjogersten and Wookey, 2004; Winterdahl et al., 2011). The interpretation of dominant discharge-independent DOC dynamics is consistent with several studies highlighting explicitly the connection between sub-annual variations in soil water DOC (akin to the DOC release time scale) and stream concentrations (e.g., Seibert et al., 2009; Clark et al., 2005).

Furthermore, by quantifying the DOC concentration fluctuations around the temporal mean or median value and comparing them with the fluctuations implied by the mechanistic model solution for different $1 / k$ values, we can get a rough estimate of what the prevailing average DOC release time scale $1 / k$ may actually be in the Abiskojokken catchment. Recent work by Jawitz and Mitchell (2011) has demonstrated that considering the ratio of the variances of log-transformed loads and log-transformed flows may provide improved understanding of the interplay between concentrations and loads in relation to chemostasis. By adopting such an approach, analytical solutions for the solute export equations describing the correlation between mass fluxes and discharge (such as that seen in Fig. 8) may still be possible. Characteristic fluctuations around the mean are calculated here as the range between the maximum and minimum value in relation to the mean, whereas fluctuations around the median are calculated as the difference between the 90th and 10 th percentile in relation to the median. For the mechanistic model, a $1 / k$ value of about $0.1 \mathrm{yr}$ then gives relative fluctuations of normalized flux-average DOC concentration (and normalized mass flux) of about $40 \%$ around the mean and $22 \%$ around the median value (Fig. $4 \mathrm{~b}$ ). This is consistent
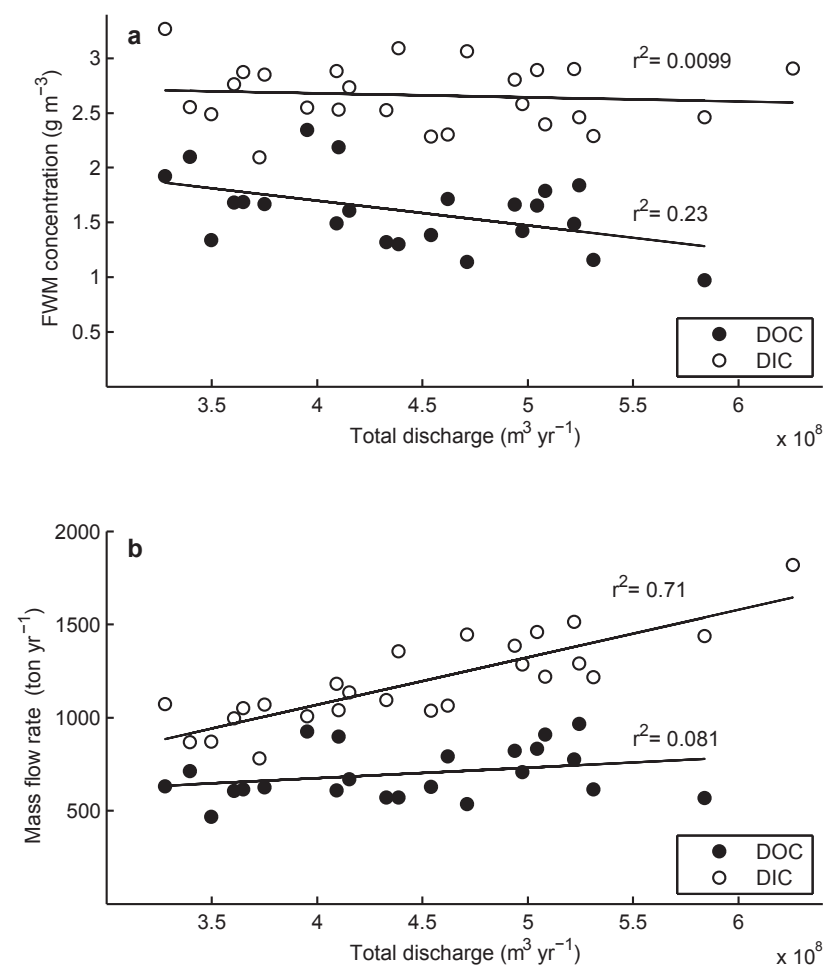

Fig. 8. Dissolved carbon discharge relationships. (a) Annual flowweighted mean (FWM) of DOC and DIC versus annual discharge at the outlet of Abiskojokken catchment. (b) Annual mass flow rate of DOC and DIC versus annual discharge at the outlet of Abiskojokken catchment; the relation between mass flow rate, $S$, and mass flux, $s$, is as shown in Fig. 2.

with the relative fluctuations of annual flow-weighted average DOC concentration in the observed time series data, which are 43 and $27 \%$ around the mean and median value, respectively (Fig. 7a). Furthermore, a DOC release time scale of $0.1 \mathrm{yr}$ matches the time period of the spring freshet, while a release time scale of up to around $0.4 \mathrm{yr}$ corresponds to the period of the wet summer season with shallow flow pathways for Abiskojokken (Lyon et al., 2010). This is in line with previous conceptual understanding of DOC export from these landscapes (Smedberg et al., 2006).

Considering further the observed annual flow-weighted average DIC concentration, it exhibits lower fluctuations around both its mean $(22 \%)$ and median $(14 \%)$ concentration value than (the corresponding 43 and $27 \%$ of) the DOC concentration (all calculated from the time series in Fig. 7a). Moreover, while the observed DOC mass flux fluctuations (from the time series in Fig. 7b) are similar (36 and $27 \%$ around the mean and the median mass flux value, respectively) to those of the DOC concentration (of 43 and $27 \%$, respectively), the corresponding DIC mass flux fluctuations of 44 and $23 \%$ are higher than the DIC concentration fluctuations (of 22 and 14\%). The temporal variability in DIC mass flux can largely be explained by the temporal discharge variability (Fig. 8b) in combination with the relatively small 
DIC concentration fluctuations. These findings further support the modeling expectation of the discharge $\left(q_{\mathrm{s}}\right)$ temporal variability being greater and more important for the DIC mass flux than the temporal variability of the other involved hydrological parameters $(\theta, \tau)$.

\section{Conclusions}

The results of this study show that the releases of organic and inorganic carbon and the corresponding export dynamics of DOC and DIC function on widely different time scales in the investigated field case of the Abiskojokken catchment. Furthermore, they depend differently on the subsurface conditions and spatiotemporal variability of different hydrological/hydrogeological (HH) and solute-specific (SS) factors in the catchment.

The overall export concentration and mass flux levels of both DOC and DIC depend on: (i) the respective (SS) bulk concentration $\left(c^{*}\right)$ in the subsurface source zones of DOC and DIC, and (ii) the relation between the $(\mathrm{HH})$ average advective solute travel time $(\tau)$ and the (SS) characteristic release time $(1 / k)$ of DOC and DIC from their respective ubiquitous source inputs along the subsurface transport pathways to the receiving stream. Furthermore, for both the concentration and the mass flux of DOC (iii) the spatial $(\mathrm{HH})$ variability of travel times $(\tau)$ among the different subsurface flow and transport pathways to the stream controls the fluctuations around the overall mean DOC level. In contrast, the fluctuations in DIC mass flux (iv) depend to a large degree on the temporal $(\mathrm{HH})$ variability of discharge into the stream $\left(q_{\mathrm{s}}\right)$, while the smaller DIC concentration fluctuations (v) may for instance depend on and reflect the effects of temporal $(\mathrm{HH})$ variability in other flow and transport parameters $(\theta, \tau)$.

By distinguishing in this way the role of different solutespecific and hydrological/hydrogeological factors, with the latter being similar for different solutes in the same catchment, these results can facilitate further and improved quantification and projection of how climate-driven and hydrologically mediated and propagated changes in catchments can affect the magnitude and dynamics of DOC and DIC export to streams. The present study has combined relatively long data time series with mechanistic model conceptualization and hypothesis formulation to identify and quantify the dominant solute release and transport processes for the main dynamic features in the time series of the observation data. This approach can more generally help in clarifying the connections between stream chemistry dynamics of DOC, DIC and other types of solute, and their hydroclimatic controls and conditions along diffuse subsurface sources and pathways, which feed into the stream networks of regional catchments in different parts of the world.

\section{Appendix}

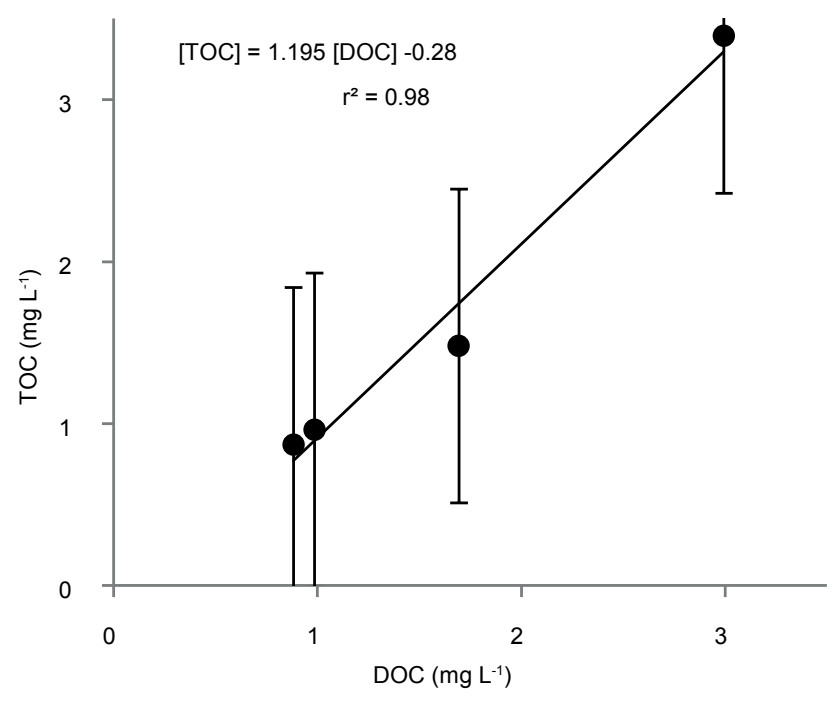

Fig. A1. Concentrations of TOC and DOC for Abiskojokken outlet, measured within a range of 3-5 days. TOC concentration was measured on a monthly basis whereas DOC was measured between 2 and 9 times per month. The measurements were conducted from April to July 2008 and the bars show minimum and maximum TOC values measured for the same months.

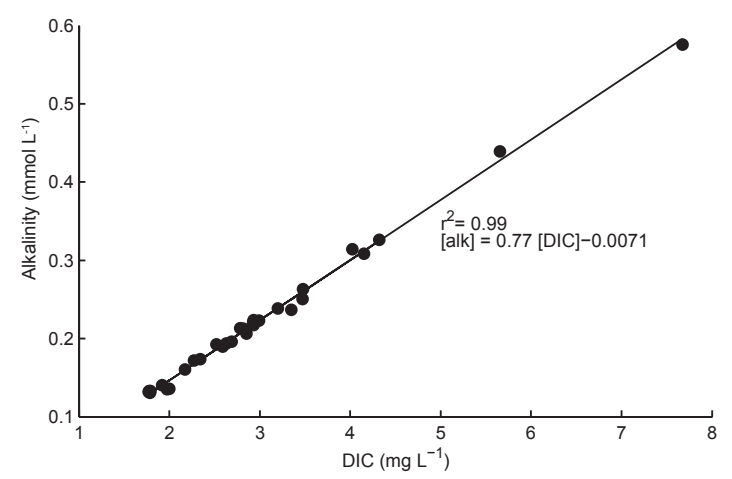

Fig. A2. Daily concentrations of alkalinity and DIC for Abiskojokken outlet for entire April 2008.

Acknowledgements. This study was supported with funding from the Swedish Research Council (VR) (project number 2007-8393) and the Swedish Geological Survey (SGU) (Project Number 60-1626).

Edited by: Y. Fan 


\section{References}

ACIA: Impacts of a Warming Arctic: Arctic Climate Impact Assessment, Cambridge Universtiy Press, Cambridge, UK, 2005.

Allen, C. E., Darmody, R. G., Thorn, C. E., Dixon, J. C., and Schlyter, P.: Clay mineralogy, chemical weathering and landscape evolution in Arctic-Alpine Sweden, Geoderma, 99, 277294, 2001.

Basu, N. B., Destouni, G., Jawitz, J. W., Thompson, S. E., Loukinova, N. V., Darracq, A., Zanardo, S., Yaeger, M., Sivapalan, M., Rinaldo, A., and Rao, P. S. C.: Nutrient loads exported from managed catchments reveal emergent biogeochemical stationarity, Geophys. Res. Lett., 37, L23404, doi:10.1029/2010GL045168, 2010.

Berner, R. A.: Weathering, plants, and the long-term carbon cycle, Geochim. Cosmochim. Ac., 56, 3225-3231, doi:10.1016/00167037(92)90300-8, 1992.

Bosson, E., Sabel, U., Gustafsson, L.-G., Sassner, M., and Destouni, G.: Influences of shifts in climate, landscape, and permafrost on terrestrial hydrology, J. Geophys. Res., 117, D05120, doi:10.1029/2011JD016429, 2012.

Box, G. E. P., Jenkins, G. M., and Reinsel, G. C.: Time series analysis: forecasting and 474 control, Wiley series in probability and statistics, 99-3448675-X, Wiley, Oxford, 2008.

Brown, J., Ferrians Jr., O. J., Heginbottom, J. A., and Melnikov, E. S.: Circum-Arctic map of permafrost and ground-ice conditions, revised February 2001 Edn., NSIDC/WDC for Glaciology, Boulder, CO, Digital media, 1998.

Burgman, J. O., Calles, B., and Westman, F.: Conclusions from a ten year study of oxygen-8 in precipitation and runoff in Sweden, in: Isotope techniques in water resources development. IAEA Division of Publications, ISBN 92-0-040087-6, 815 pp., 1987.

Callaghan, T. V., Bergholm, F., Christensen, T. R., Jonasson, C., Kokfelt, U., and Johansson, M.: A new climate era in the subArctic: Accelerating climate changes and multiple impacts, Geophys. Res. Lett., 37, L14705, doi:10.1029/2009GL042064, 2010.

Carey, S. K.: Dissolved organic carbon fluxes in a discontinuous permafrost subarctic alpine catchment, Permafrost Periglac., 14, 161-171, 2003.

Carey, S. K. and Quinton, W. L.: Evaluating snowmelt runoff generation in a discontinuous permafrost catchment using stable isotope, hydrochemical and hydrometric data, Nord. Hydrol., 35, 309-324, 2004.

Carey, S. K. and Woo, M. K.: Spatial variability of hillslope water balance, wolf creek basin, subarctic yukon, Hydrol. Process., 15, 3113-3132, 2001.

Clark, J. M., Chapman, P. J., Adamson, J. K., and Lane, S. N.: Influence of drought-induced acidification on the mobility of dissolved organic carbon in peat soils, Global Change Biol., 11, 791-809, 2005.

Cole, J. J., Prairie, Y. T., Caraco, N. F., McDowell, W. H., Tranvik, L. J., Striegl, R. G., Duarte, C. M., Kortelainen, P., Downing, J. A., Middelburg, J. J., and Melack, J.: Plumbing the Global Carbon Cycle: integrating inland waters into the terrestrial carbon budget, Ecosystems, 10, 171-184, 2007.

Cvetkovic, V.: The tempered one-sided stable density: a universal model for hydrological transport?, Environ. Res. Lett., 6, 034008, doi:10.1088/1748-9326/6/3/034008, 2011.
Cvetkovic, V. and Dagan, G.: Transport of kinetically sorbing solute by steady random velocity in heterogeneous porous formations, J. Fluid. Mech., 265, 189-215, doi:10.1017/S0022112094000807, 1994.

Cvetkovic, V., Carstens, C., Selroos, J.-O., and Destouni, G.: Water and solute transport along hydrological pathways, Water Resour. Res., 48, W06537, doi:10.1029/2011wr011367, 2012.

Dahlke, H. E., Lyon, S. W., Stedinger, J. R., Rosqvist, G., and Jansson, P.: Contrasting trends in floods for two sub-arctic catchments in northern Sweden - does glacier presence matter?, Hydrol. Earth Syst. Sci., 16, 2123-2141, doi:10.5194/hess-16-21232012, 2012.

Darmody, R. G., Thorn, C. E., Dixon, J. C., and Schlyter, P.: Soils and landscapes of Karkevagge, Swedish Lapland, Soil Sci. Soc. Am. J., 64, 1455-1466, 2000.

Darracq, A., Destouni, G., Persson, K., Prieto, C., and Jarsjo, J.: Quantification of advective solute travel times and mass transport through hydrological catchments, Environ Fluid Mech., 10, 103120, 2010.

Destouni, G. and Graham, W. D.: Solute transport through an integrated heterogeneous soil-groundwater system, Water Resour. Res., 31, 1935-1944, doi:10.1029/95WR01330, 1995.

Destouni, G. and Cvetkovic, V.: Field scale mass arrival of sorptive solute into the groundwater, Water Resour. Res., 27, 1315-1325, doi:10.1029/91WR00182, 1991.

Destouni, G., Persson, K., Prieto, C., and Jarsjo, J.: General quantification of catchment-scale nutrient and pollutant transport through the subsurface to surface and coastal waters, Environ. Sci. Technol., 44, 2048-2055, 2010.

Dixon, J. C., Thorn, C. E., and Darmody, R. G.: Spatial Scale and Chemical Weathering in Karkevagge: Influences on Landscape Evolution, Z. Geomorph., 52, 27-49, doi:10.1127/03728854/2008/0052S1-0027, 2008.

Durbin, J. and Watson, G. S.: Testing for serial correlation in least squares regression, I, Biometrika, 37, 409-428, 1950.

Durbin, J. and Watson, G. S.: Testing for serial correlation in least squares regression, II, Biometrika, 38, 159-178, 1951.

Durbin, J. and Watson, G. S.: Testing for serial correlation in least squares regression, III, Biometrika, 58, 1-19, 1971.

Eriksson, N. and Destouni, G.: Combined effects of dissolution kinetics, secondary mineral precipitation, and preferential flow on copper leaching from mining waste rock, Water Resour. Res., 33, 471-483, 1997.

Frampton, A., Painter, S., Lyon, S. W., and Destouni, G.: Nonisothermal, three-phase simulations of near-surface flows in a model permafrost system under seasonal variability and climate change, J. Hydrol., 403, 352-359, 2011.

Fung, I. Y., Doney, S. C., Lindsay, K., and John, J.: Evolution of carbon sinks in a changing climate, P. Natl. Acad. Sci. USA, 102, 11201-11206, 2005.

Giesler, R., Mörth, C. M., Karlsson, J., Lundin, E. J., Lyon, S. W., Humborg, C.: Spatiotemporal variations of $p \mathrm{CO}_{2}$ and $\delta^{13} \mathrm{C}$-DIC in subarctic streams in northern Sweden, Global Biogeochem. Cy., 27, 176-186, doi:10.1002/gbc.20024, 2013.

Godsey, S. E., Kirchner, J. W., and Clow, D. W.: Concentrationdischarge relationships reflect chemostatic characteristics of US catchments, Hydrol. Process., 23, 1844-1864, 2009. 
Harden, J. W., Sharpe, J. M. Parton, W. J., Ojima, D. S., Fries, T. L., Huntington, T. G., Dabney, S. M., Dynamic replacement and loss of soil carbon on eroding cropland, Global Biogeochem. Cy., 13, 885-901, doi:10.1029/1999GB900061, 1999.

Hobbie, S. E., Schimel, J. P., Trumbore, S. E., and Randerson, J. R.: Controls over carbon storage and turnover in high-latitude soils, Change Biol., 6, 196-210, 2000.

Jawitz, J. W. and Mitchell, J.: Temporal inequality if catchment discharge and solute export, Water Resour. Res., 47, W00J14, doi:10.1029/2010WR010197, 2011.

Johansson, M., Christensen, T. R., Akerman, H. J., and Callaghan, T. V.: What determines the current presence or absence of permafrost in the Tornetrask region, a sub-arctic landscape in Northern Sweden?, Ambio, 35, 190-197, 2006.

Kawahigashi, M., Kaiser, K., Rodionov, A., and Guggenberger, G.: Sorption of dissolved organic matter by mineral soils of the Siberian forest tundra, Global Change Biol., 12, 1868-1877, doi:10.1111/j.1365-2486.2006.01203.x, 2006.

Kling, G. W., Kipphut, G. W., and Miller, M. C.: Arctic Lakes and Streams as Gas Conduits to the Atmosphere: Implications for Tundra Carbon Budgets, Science, 251, 298-301, 1991.

Kneisel, C.: Frozen ground conditions in a subarctic mountain environment, Northern Sweden, Geomorphology, 118, 80-92, 2010.

Kulling, O. and Geijer, P.: Sveriges geologiska undersökning. The Caledonian mountain chain in the Tornetrask-Ofoten area, northern, Scandinavia; the Kiruna iron ore field, Swedish Lapland: guide to excursions nos. A 25 and C 20, Geological Survey of Sweden, 1960.

Lindgren, G. A., Destouni, G., and Miller, A. V.: Solute transport through the integrated groundwater-stream system of a catchment, Water Resour. Res., 40, W03511, doi:10.1029/2003wr002765, 2004.

Lyon, S. W., Destouni, G., Giesler, R., Humborg, C., Mörth, M., Seibert, J., Karlsson, J., and Troch, P. A.: Estimation of permafrost thawing rates in a sub-arctic catchment using recession flow analysis, Hydrol. Earth Syst. Sci., 13, 595-604, doi:10.5194/hess-13-595-2009, 2009.

Lyon, S. W., Mörth, M., Humborg, C., Giesler, R., and Destouni, G.: The relationship between subsurface hydrology and dissolved carbon fluxes for a sub-arctic catchment, Hydrol. Earth Syst. Sci., 14, 941-950, doi:10.5194/hess-14-941-2010, 2010.

Lyon, S. W., Grabs, T., Laudon, H., Bishop, K. H., and Seibert, J.: Variability of groundwater levels and total organic carbon in the riparian zone of a boreal catchment, J. Geophys. Res., 116, G01020, doi:10.1029/2010JG001452, 2011.

MacLean, R., Oswood, M. W., Irons, J. G., and McDowell, W. H.: The effect of permafrost on stream biogeochemistry: A case study of two streams in the Alaskan (USA) Taiga, Biogeochemistry, 47, 239-267, 1999.

McNamara, J. P., Kane, D. L., Hobbie, J. E., and Kling, G. W.: Hydrologic and biogeochemical controls on the spatial and temporal patterns of nitrogen and phosphorus in the Kuparuk River, arctic Alaska, Hydrol. Process., 22, 3294-3309, 2008.

Olefeldt, D., Roulet, N., Giesler, R., Persson,A.: Total waterbourne carbon export and DOC composition from ten nested subarctic catchements - importance of peatland cover, groundwater influence, and inter-annual variability of precipitation patterns, Hydrol. Process., 27, 2280-2294, doi:10.1002/hyp.9358, 2012.
Persson, K., Jarsjö, J., and Destouni, G.: Diffuse hydrological mass transport through catchments: scenario analysis of coupled physical and biogeochemical uncertainty effects, Hydrol. Earth Syst. Sci., 15, 3195-3206, doi:10.5194/hess-15-3195-2011, 2011.

Petrone, K. C., Jones, J. B., Hinzman, L. D., and Boone, R. D.: Seasonal export of carbon, nitrogen, and major solutes from Alaskan catchments with discontinuous permafrost, J. Geophys. Res., 111, G02020, doi:10.1029/2005jg000055, 2006.

Rafstedt, T., Andersson, L., and Sydow, U. V.: Fjällens vegetation. Norrbottens län : en översikt av Norrbottenfjällens vegetation baserad på vegetationskartering och naturvärdering, Norrbottens county: a survey on the basis of vegetation mapping and assessment of natural values, Rapporter/Statens naturvårdsverk, 03478173, Statens naturvårdsverk, Solna, 1985.

Ridefelt, H., Etzelmüller, B., Boelhouwers, J., and Jonasson, C.: Statistic-empirical modelling of mountain permafrost distribution in the Abisko region, sub-Arctic northern Sweden, Norsk. Geogr. Tidsskr., 62, 278-289, 2008.

Schuur, E. A. G., Bockheim, J., Canadell, J. G., Euskirchen, E., Field, C. B., Goryachkin, S. V., Hagemann, S., Kuhry, P., Lafleur, P. M., Lee, H., Mazhitova, G., Nelson, F. E., Rinke, A., Romanovsky, V. E., Shiklomanov, N., Tarnocai, C., Venevsky, S., Vogel, J. G., and Zimov, S. A.: Vulnerability of permafrost carbon to climate change: implications for the global carbon cycle, Bioscience, 58, 701-714, 2008.

Seibert, J., Grabs, T., Köhler, S., Laudon, H., Winterdahl, M., and Bishop, K.: Linking soil- and stream-water chemistry based on a Riparian Flow-Concentration Integration Model, Hydrol. Earth Syst. Sci., 13, 2287-2297, doi:10.5194/hess-13-22872009, 2009.

Sjogersten, S. and Wookey, P. A.: Decomposition of mountain birch leaf litter at the forest-tundra ecotone in the Fennoscandian mountains in relation to climate and soil conditions, Plant Soil, 262, 215-227, doi:10.1023/B:PLSO.0000037044.63113.fe, 2004.

Sjöberg, Y., Frampton, A., and Lyon, S. W.: Using streamflow characteristics to explore permafrost thawing in Northern Swedish catchments, Hydrogeol. J., 21, 121-131, doi:10.1007/s10040012-0932-5, 2013.

Smedberg, E., Mörth, C.-M., Swaney, D. P., and Humborg, C.: Modeling hydrology and silicon-carbon interactions in taiga and tundra biomes from a landscape perspective: implications for global warming feedbacks, Global Biogeochem. Cy., 20, GB2014, doi:10.1029/2005GB002567, 2006.

Smedberg, E., Humborg, C., Jakobsson, M., and Mörth, C.-M.: Landscape elements and river chemistry as affected by river regulation - a 3-D perspective, Hydrol. Earth Syst. Sci., 13, 15971606, doi:10.5194/hess-13-1597-2009, 2009.

Tank, S. E., Raymond, P. A., Striegl, R. G., McClelland, J. W., Holmes, R. M., Fiske, G. J., and Peterson, B. J.: A land-to-ocean perspective on the magnitude, source and implication of DIC flux from major Arctic rivers to the Arctic Ocean, Global Biogeochem. Cy., 26, GB4018, doi:10.1029/2011GB004192, 2012.

Tranvik, L. J., Downing, J. A., Cotner, J. B., Loiselle, S. A., Striegl, R. G., Ballatore, T. J., Dillon, P., Finlay, K., Fortino, K., and Knoll, L. B.: Lakes and reservoirs as regulators of carbon cycling and climate, Limnol. Oceanogr., 54, 2298-2314, 2009. 
Turner, R. E. and Rabalais, N. N.: Linking Landscape and Water Quality in the Mississippi River Basin for 200 Years, BioScience, 53, 563-572, doi:10.1641/00063568(2003)053[0563:LLAWQI]2.0.CO;2, 2003.
Winterdahl, M., Futter, M., Kohler, S., Laudon, H., Seibert, J., and Bishop, K.: Riparian soil temperature modification of the relationship between flow and dissolved organic carbon concentration in a boreal stream, Water Resour. Res., 47, G04S54, doi:10.1029/2006jg000353, 2011. 